\title{
Pusat Rehabilitasi Penyandang Hiv/Aids Di Pekanbaru
}

\author{
Putri Wulansari ${ }^{1}$, Titin Sundari ${ }^{2}$, Benny Hermawan ${ }^{3}$ \\ Program Studi Arsitektur, Fakultas Teknik, Universitas Lancang Kuning \\ Jl. Yos Sudarso km. 8 Rumbai, Pekanbaru, Telp. (0761) 52324 \\ Email: putri.arend07@gmail.com, titin@unilak.ac.id,penulis3@unilak.ac.id
}

\begin{abstract}
ABSTRAK
HIV (Human Immunodeficiency Virus) merupakan virus yang menyebabkan AIDS (Acquired Immune Deficiency Syndrome) adalah penyebab kematian yang tinggi di dunia. Kemenkes Republik Indonesia mengatakan pada tahun 2012 jumlah AIDS menembus angka 100.000 jiwa dengan 5.430 kematian, hal itu menjadikan Indonesia mendapat peringkat ke 3 di Asia dengan percepatan jumlah kasus HIV yang terus naik dari tahun ke tahun.

Peningkatan kasus HIV/AIDS perlu di tindak lanjuti dengan penyediaan tempat Rehabilitasi bagi ODHA (Orang Dengan HIV/AIDS), untuk mengobati penderita AIDS agar penyebaran virus HIV di masyarakat dapat menurun. Secara keselurahan di Indonesia baru terdapat tiga tempat yang memfasilitasi perawatan bagi ODHA, melihat permasalahan ini maka muncul gagasan untuk membuat perencanaan Pusat Rehabilitas Penyandang HIV/AIDS di Pekanbaru dengan pendekatan arsitektur organik yang dipengaruhi oleh site eksisting. Konsep arsitektur organik yang dinamis serta keselarasan bentuk bangunan dengan lingkungan diharapkan mampu memfasilitasi kebutuhan penyandang HIV akan ketenangan dan kenyamanan dalam bangunan serta rasa optimisme untuk sembuh dan dapat bersosialisasi kembali di masyarakat.
\end{abstract}

Kata Kunci: HIV, AIDS, Pusat Rehabilitasi,

\begin{abstract}
HIV HIV (Human Immunodeficiency Virus) is a cirus that causes AIDS (Acquired Immune Deficiency Syndrome) is the causes of high death in the world. Kemenkes the The Ministry of Health of Indonesia said in 2012 the amount od AIDS penetrated the number of 100.000 souls with 5.430 deaths, it made Indonesia get ranked to 3 in Asia with the acceleration of the number in cases that terys uo from year to year.

The increase in HIV / AIDS case needs to follow up with the provision of rehabilitation for ODHA (People with HIVIAIDS), to treat AIDS to the spread of HIV virus in society can decrease. Overall in Indonesia there are threen places that facilitate treatment for ODHA, seeing this issue then appears the idea to make the planning if HIV / AIDS Rehabilitation Center in Pekanbaru with an Organic Architecture approach affected by the site. The concept of dynamic organic architecture as well as the alignment of building froms with the environment is expected to be able to facilitate the needs of HIV and comfort in the building and the sense of optimisme to heal and be able to.
\end{abstract}

Keywords: HIV, AIDS, Rehabilitation Center, 


\section{PENDAHULUAN}

HIV (Human Immunodeficiency Virus) dan AIDS (Acquired Immune Deficiency Syndrome) merupakan sebuah virus yang menyerang sistem kekebalan tubuh pada manusia. HIV merupakan penyakit menular dengan angka kematian yang tinggi di Dunia, penyebaran virus ini menjangkit seluruh lapisan masyarakat, tanpa terkecuali mulai bayi hingga dewasa.

Menurut laporan Kemenkes Republik Indonesia tahun 2012 jumlah AIDS sudah menembus angka 100.000 jiwa dengan 5.430 kematian. Hal tersebut menjadikan Indonesia peringkat ke 3 negara di Asia dengan percepatan jumlah kasus HIV tertinggi setelah Cina dan India. Data terakhir yang dihimpun Komisi Penanggulangan Aids (KPA) Provinsi Riau terdapat 1.821 kasus tersebar di seluruh Provinsi Riau, dari 12 Kabupaten/Kota se-Provinsi Riau, Pekanbaru di predikat angka tertinggi penyebaran virus HIV.

Menurut Komisi Penanggulangan AIDS (KPA) Kota Pekanbaru mencatat di tahun 2015 terdapat 352 kasus, dengan 241 HIV dan 111 AIDS. Kenaikan kasus HIV dan AIDS terjadi di tahun 2016 sebanyak 30\% dengan total 448 kasus. Total kumulatif kasus HIV/AIDS di Pekanbaru dari tahun 2000 sampai 2016 lalu mencapai 2.165 kasus, terdiri atas 1.159 (HIV) dan 1.006 (AIDS).

Dari peningkatan kasus HIV/AIDS di Pekanbaru, perlu diberi tindakan lanjut terutama terhadap penyediaan tempat Rehabilitas bagi ODHA (Orang Dengan HIV/AIDS). Perencanaan tempat Rehabilitas diharapkan mampu menampung kebutuhan serta fasilitas-fasilitas yang dibutuhkan bagi penderita HIV/AIDS di Pekanbaru, agar penyebaran dan tingkat angka kematian akibat HIV dapat menurun di tahun-tahun berikutnya.

Perencanaan Pusat Rehabilitasi HIV/AIDS di Pekanbaru dengan pendekatan rancangan terhadap prinsip-prinsip Arsitektur Organik. Arsitektur organik adalah jenis arsitektur yang menitik beratkan harmoni antara tempat tinggal dengan alam di sekitarnya.

\section{METODE PENELITIAN}

Metode yang digunakan untuk mendapatkan datadata terkait dengan perancangan "Pusat Rehabilitasi Penyandang HIV/AIDS di Pekanbaru" antara lain:

\section{Studi Literatur}

Memperoleh data dan informasi dengan cara menelaah buku-buku yang berkaitan dengan judul, baik berupa tugas akhir, jurnal dan laporan seminar.

\section{Studi Empiris}

Melakukan penelitian secara langsung maupun tidak langsung terhadap dengan judul bangunan sejenis

\section{Studi Lapangan}

Melakukan tinjauan ke lapangan terkait dengan data yang dibutuhkan.

\section{Wawancara}

Melakukan tanya jawab kepada narumber untuk mendapatkan informasi terkait dengan data yang dibutuhkan.

\section{HASIL DAN PEMBAHASAN}

Lokasi perencanaan terletak di jalan Pramuka Kecamatan Rumbai Pesisir, Kota Pekanbaru. Pemilihan lokasi tersebut didasari oleh kebutuhan Pusat Rehabilitasi yang membutuhkan lokasi yang tenang dan jauh dari perkotaan.

\section{Aspek Tapak}

Lokasi tapak terletak di Wilayah Pengembangan (WP) III, pengembangan difokuskan pada kegiatan permukiman, pendidikan, pertanian, kawasan lindung, olahraga dan rekreasi.

Dimensi Tapak

Luas tapak perencanaan Pusat Rehabilitasi Penyandang HIV/AIDS di Pekanbaru adalah $14.804,07 \mathrm{~m}^{2}$ dengan view menghadap jalan Pramuka (arah utara) dan membelakangi view mengarah ke Kota Pekanbaru (arah selatan)

Batas-Batas Tapak

a) Batas tapak sebelah timur ialah Jalan Pramuka

b) Batas tapak sebelah barat ialah lahan kosong yang ditumbuhi semak belukar

c) Batas tapak sebelah utara ialah Jalan Pramuka

d) Batas tapak sebelah selatan ialah lahan kosong

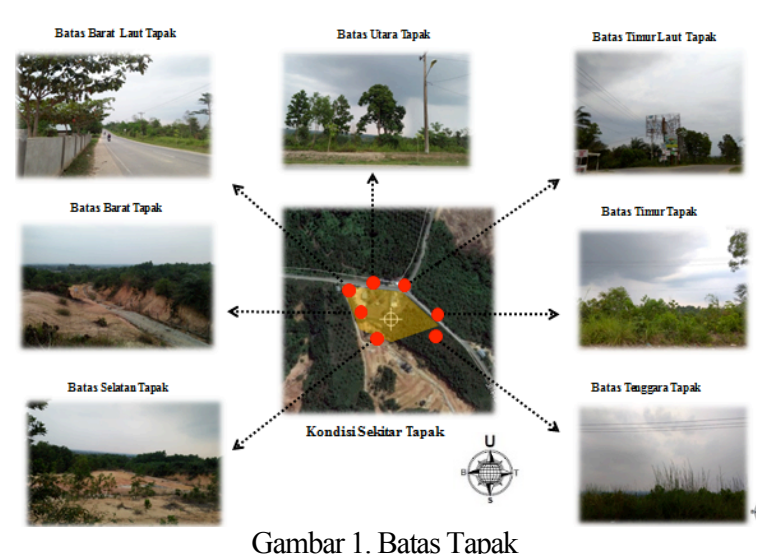

Analisis Regulasi

Koefisien Dasar Bangunan (KDB)

KDB menurut Perda kota Pekanbaru no.7 tahun 2012, ditentukan KDB maksimum 50\% untuk bangunan fungsi sosial. Nilai KDB 50\% dari luas lahan adalah $7.402,35 \mathrm{~m}^{2}$

Koefisen Lantai Bangunan (KLB)

KLB menurut Perda kota Pekanbaru no.7 tahun 2012, ditentukan KLB maksimum 0,45 untuk bangunan fungsi sosial. Nilai KLB 0,50 dari luas lahan adalah $7.402,035 \mathrm{~m}^{2}$

Garis Sempadan Bangunan (GSB)

GSB menurut Perda kota Pekanbaru no.7 tahun 2012 untuk Jalan Pramuka adalah 24 meter dari as jalan. 


\section{Analisis Topografi}

Kondisi topografi tapak adalah tanah berkontur dengan jenis tanah podsolik Merah Kuning (PMK). Jenis tanah ini memiliki daya dukung yang baik dengan kedalaman tanah keras berkisar 10-15 meter

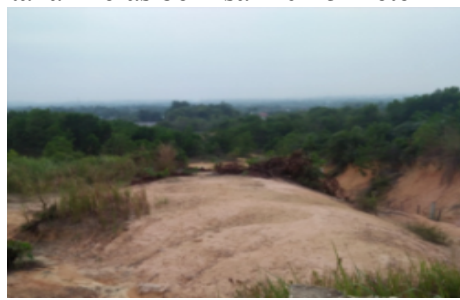

Gambar 2. Jenis Tanah

\section{Analisis Orientasi Matahari}

Analisis matahari pada tapak bertujuan mengetahui daerah mana yang akan mendapat cahaya dan panas matahari lebih banyak dan lebih sedikit. Pada tapak orientasi tapak menghadap arah utara, berpengaruh terhadap besar bidang bukaan yang akan di rencanakan

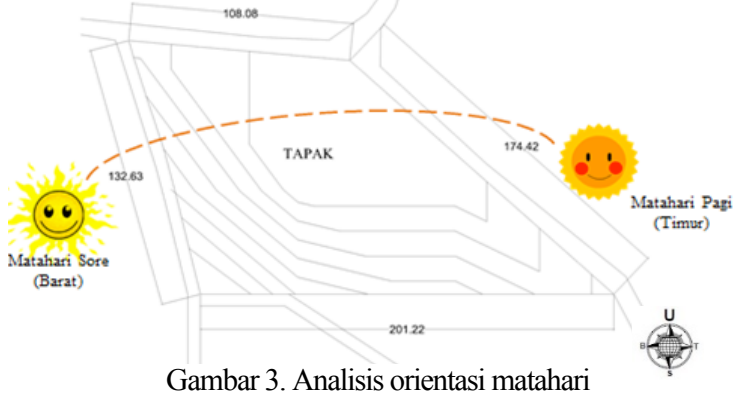

\section{Analisis Kebisingan}

Tingkat kebisingan bersumber dari 2 arah yaitu dari Jalan Pramuka dan Jalan Limbungan. Dari ke 2 arah tersebut memiliki kebisingan yang relatif sedang.

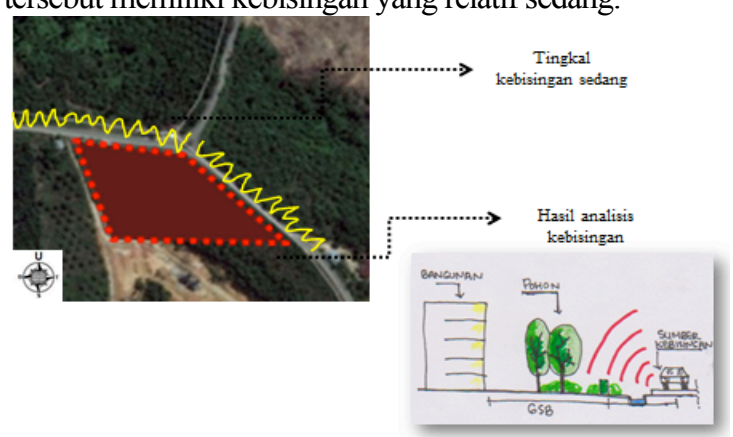

Gambar 4. Analisis Kebisingan

Tingkat kebisingan yang relatif sedang dapat di analisis dengan menanam pohon tanjung di area depan tapak, serta memanfaatkan GSB 24 meter dari As Jalan sebagai salah satu analisis dari sumber kebisingan.

\section{Analisis Pencapaian}

Lokasi tapak berada cukup jauh dari Pusat Kota

Pekanbaru, waktu tempuh dengan kendaraan pribadi roda 4 dan roda 2 dari Jalan Sudirman menuju lokasi tapak sekitar 25 menit, sedangkan dengan berjalan kaki kurang lebih 2 jam. Untuk akses menggunakan angkutan umum pemberhentian terakhir di persimpangan Jalan Pramuka dan Jalan Limbungan.

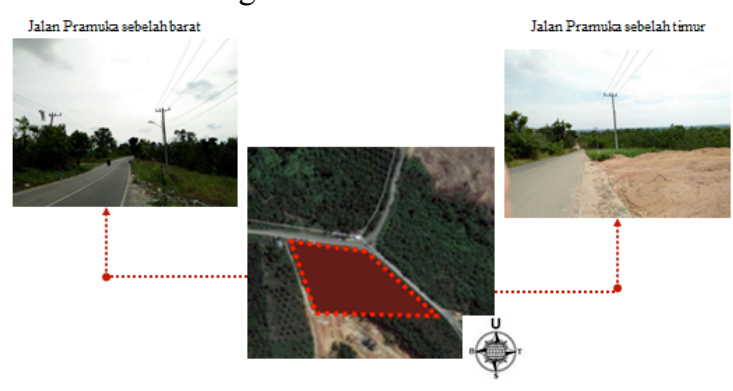

Gambar 5. Analisis pencapaian tapak

\section{Analisis Sirkulasi}

Sirkulasi di luar tapak melalui jalan satu arah, yaitu jalan Pramuka. Untuk sirkulasi di dalam tapak, terbagi menjadi dua, sirkulasi pengujung yeng melewati depan bangunan dan sirkulasi untuk rehabilitasi medis yang mengitari setengah bangunan karena akses keluar yang berbeda dengan pengunjung.

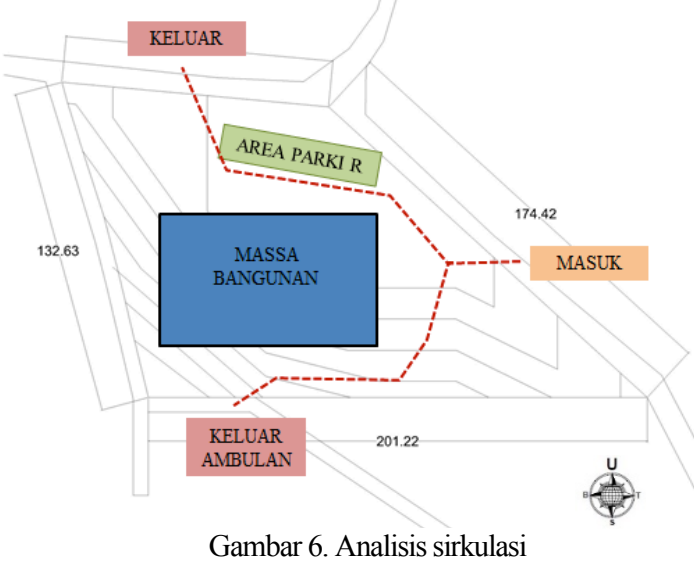

Aspek Manusia

Manusia merupakan faktor utama yang sangat berpengaruh terhadap desain sebuah bangunan yang akan direncanakan. Adapun aspek yang perlu diperhatikan, yaitu :

\section{Analisis Pelaku Kegiatan}

A. Pengelola

Manajemen, Pemeliharaan dan Perawatan dan Keamanan

B. Pengelola Rehabilitasi

Rehabilitasi Medis, Rehabilitasi Sosial Rehabilitasi Lingkungan

C. Penyandang HIV/AIDS

Penyandang HIV Stadium 1, Penyandang HIV Stadium 2, Penyandang HIV Stadium 3, Penyandang HIV Stadium 4

D. Pengunjung

Keluarga, Kerabat dan Teman, Instansi Sosial 


\section{Analisis Kegiatan dan Kebutuhan Ruang}

Setelah didapatkan analisis pelaku kegiatan akan dianalisis aktivitas pelaku dan kebutuhan ruang yang diperlukan oleh penyandang HIV/AIDS. (lihat tabel 1)

Tabel 1. Analisis kegiatan dan kebutuhan ruang

\begin{tabular}{|c|c|c|c|c|}
\hline \multirow[t]{7}{*}{1} & \multirow[t]{7}{*}{ Pengelola } & $\begin{array}{l}\text { Kepala Pusat } \\
\text { Rehabilitasi }\end{array}$ & $\begin{array}{l}\text { - Datang } \\
\text { - Pengecekan } \\
\text { lapangan } \\
\text { - Rapat } \\
\text { - Isoma } \\
\text { - Pulang } \\
\end{array}$ & $\begin{array}{l}\text { - Parkir } \\
\text { - R. Kepala pusat } \\
\text { - R. Kepala bagian } \\
\text { - R. Rapat } \\
\text { - Masjid } \\
\text { - Toilet } \\
\end{array}$ \\
\hline & & $\begin{array}{l}\text { Kabag } \\
\text { Umum dan } \\
\text { ADM }\end{array}$ & $\begin{array}{l}\text { - Datang } \\
\text { - Bekerja } \\
\text { - Isoma } \\
\text {-Pulang }\end{array}$ & $\begin{array}{l}\text { - Parkir } \\
\text { - R. Kerja } \\
\text { - R. Istirahat } \\
\text { - Masjid } \\
\text { - Toilet }\end{array}$ \\
\hline & & $\begin{array}{l}\text { Pemeliharaa } \\
\text { n dan } \\
\text { Perawatan }\end{array}$ & $\begin{array}{l}\text { Datang } \\
\text { Membersihkan } \\
\text { ruangan } \\
\text { Isoma } \\
\text { Pulang }\end{array}$ & $\begin{array}{l}\text { - Parkir } \\
\text { - OB } \\
\text { - R. Istirahat } \\
\text { - Masjid } \\
\text { - Toilet }\end{array}$ \\
\hline & & $\begin{array}{l}\text { Bagian } \\
\text { Keamanan }\end{array}$ & $\begin{array}{l}\text { - Datang } \\
\text { - Mengecek } \\
\text { keamanan } \\
\text { - Isoma } \\
\text { - Ganti sift } \\
\text { - Pulang }\end{array}$ & $\begin{array}{l}\text { - Parkir } \\
\text { - Pos satpam } \\
\text { - R. Istirahat } \\
\text { - Masjid } \\
\text { - Toilet }\end{array}$ \\
\hline & & $\begin{array}{l}\text { Rehabilitasi } \\
\text { Medis }\end{array}$ & $\begin{array}{l}\text { - Datang } \\
\text { - Pemeriksaan } \\
\text { harian } \\
\text { - Mengobati } \\
\text { - Isoma } \\
\text { - Pulang }\end{array}$ & $\begin{array}{l}\text { - Parkir } \\
\text { - R. Pemeriksaan } \\
\text { - R. Rawat } \\
\text { - R. Transisi } \\
\text { - R. Isolasi } \\
\text { - Masjid } \\
\text { - Toilet }\end{array}$ \\
\hline & & $\begin{array}{l}\text { Rehabilitasi } \\
\text { Sosial }\end{array}$ & $\begin{array}{l}\text { - Datang } \\
\text { - Terapi } \\
\text { prikologis } \\
\text { - Terapi religius } \\
\text { - Isoma } \\
\text { - Pulang }\end{array}$ & $\begin{array}{l}\text { - R. Terapi } \\
\text { Psikologis } \\
\text { - R. Terapi } \\
\text { emosional } \\
\text { - R. Terapi Religi } \\
\text { - R. Harapan } \\
\text { - Masjid } \\
\text { - Toilet }\end{array}$ \\
\hline & & $\begin{array}{l}\text { Rehabilitasi } \\
\text { Lingkungan }\end{array}$ & $\begin{array}{l}\text { - Datang } \\
\text { - Memberi } \\
\text { pembekalan } \\
\text { - Isoma } \\
\text { - Pulang }\end{array}$ & $\begin{array}{l}\text { - Parkir } \\
\text { - Ruang } \\
\text { Pembekalan } \\
\text { - R. Serba guna } \\
\text { - Aula } \\
\text { - Taman } \\
\text { - Toilet }\end{array}$ \\
\hline \multirow[t]{4}{*}{2} & \multirow[t]{3}{*}{$\begin{array}{l}\text { Penyandang } \\
\text { HIV/AIDS }\end{array}$} & Stadium 1 & $\begin{array}{l}\text { - Datang } \\
\text { - Pendaftaran } \\
\text { - Medical cek } \\
\text { up } \\
\text { - Konsultasi } \\
\text { - Pulang } \\
\text { - Parkir } \\
\end{array}$ & $\begin{array}{l}\text { - Parkir } \\
\text { - Resepsionis } \\
\text { - Ruang medis } \\
\text { - Ruang konsultasi } \\
\text { - Toilet }\end{array}$ \\
\hline & & Stadium 2 & $\begin{array}{l}\text { - Datang } \\
\text { - Pendaftaran } \\
\text { - Medical cek } \\
\text { up } \\
\text { - Konsultasi } \\
\text { - Pulang } \\
\text { - Parkir }\end{array}$ & $\begin{array}{l}\text { - Parkir } \\
\text { - Resepsionis } \\
\text { - Ruang medis } \\
\text { - Ruang konsultasi } \\
\text { - Toilet }\end{array}$ \\
\hline & & Stadium 3 & $\begin{array}{l}\text { - Datang } \\
\text { - Pendaftaran } \\
\text { - Medical cek } \\
\text { up } \\
\text { - Konsultasi } \\
\text { - Menginap } \\
\text { - Terapi } \\
\text { psikologis dan } \\
\text { religi } \\
\text { - Pembekalan } \\
\text { - Pulang }\end{array}$ & $\begin{array}{l}\text { - Parkir } \\
\text { - Resepsionis } \\
\text { - R. Cek up medis } \\
\text { - R. Inap } \\
\text { - R. Terapi } \\
\text { psikologis } \\
\text { - R. Terapi religi } \\
\text { - Ruang } \\
\text { Pembekalan } \\
\text { - Toilet }\end{array}$ \\
\hline & & Stadium 4 & $\begin{array}{l}\text { - Datang } \\
\text { - Pendaftaran } \\
\text { - Medical cek } \\
\text { up } \\
\text { - Menginap } \\
\text { - Masuk transisi } \\
\text { - Masuk isolasi } \\
\text { - Terapi } \\
\text { Psikologis } \\
\text { - Terapi Religi } \\
\text { - Kembali ke } \\
\text { masyarakat// } \\
\text { kembali pada } \\
\text { maha sang } \\
\text { pencipta. }\end{array}$ & $\begin{array}{l}\text { - Parkir } \\
\text { - Loby } \\
\text { - Resepsionis } \\
\text { - R. Cek up } \\
\text { - R. Transisi } \\
\text { - R. Isolasi } \\
\text { - R. Terapi } \\
\text { Psikologis } \\
\text { - R. Terapi Religi } \\
\text { - Masjid } \\
\text { - R. Pembekalan } \\
\text { - R. Harapan } \\
\text { - Toilet }\end{array}$ \\
\hline
\end{tabular}

\begin{tabular}{|c|c|c|c|c|}
\hline No & $\begin{array}{c}\text { Kelompok } \\
\text { Pelaku }\end{array}$ & Pelaku & Aktivitas & Kebutuhan Ruang \\
\hline (1) & (2) & (3) & (4) & (5) \\
\hline 3 & Pengunjung & $\begin{array}{l}\text { Keluarga, } \\
\text { kerabat, } \\
\text { teman. }\end{array}$ & $\begin{array}{l}\text { - Datang } \\
\text { - Mendaftar } \\
\text { - Menunggu } \\
\text { - Bertemu } \\
\text { penyandang } \\
\text { hiv/aids } \\
\text { - Konseling } \\
\text { - Isoma } \\
\text { - Pulang }\end{array}$ & $\begin{array}{l}\text { - Parkir } \\
\text { - Lobby } \\
\text { - Resepsionis } \\
\text { - R. Tunggu } \\
\text { - R. Kunjungan } \\
\text { - R. Konseling } \\
\text { keluarga } \\
\text { - Asrama tamu } \\
\text { - Masjid } \\
\text { - Toilet }\end{array}$ \\
\hline & & $\begin{array}{l}\text { Instansi } \\
\text { Sosial, } \\
\text { penelitian } \\
\text { dan kegiatan } \\
\text { lain }\end{array}$ & $\begin{array}{l}\text { - Datang } \\
\text { - Mendaftar } \\
\text { - Menunggu } \\
\text { - Wawancara } \\
\text { - Isoma } \\
\text { - Pulang }\end{array}$ & $\begin{array}{l}\text { - Parkir } \\
\text { - Lobby } \\
\text { - Resepsionis } \\
\text { - R. Tunggu } \\
\text { - R. Kunjungan } \\
\text { - Masjid } \\
\text { - Asrama tamu } \\
\text { - Toilet }\end{array}$ \\
\hline
\end{tabular}

Analisis Besaran Ruang

Hasil analisis pelaku kegiatan, kebutuhan ruang akan didapatkan kebutuhan ruang untuk selanjutnya dianalisis kapasitas besaran ruang yang dibutuhkan pusat rehabilitasi penyandang HIV/AIDS di Pekanbaru

Rekapitulasi besaran ruang Pusat Rehabilitasi Penyandang HIV/AIDS di Pekanbaru adalah 4366,98 $\mathrm{m}^{2}$. (lihat tabel 2.)

Tabel 2. Analisis besaran ruang
\begin{tabular}{|c|l|r|}
\hline No & \multicolumn{1}{|c|}{ Nama Fasilitas } & \multicolumn{1}{c|}{ Luas } \\
\hline 1 & FASILITAS PENERIMA AWAL & 297,3 \\
\hline 2 & R. MANAJEMEN & 371,04 \\
\hline 3 & FASILITAS REHAB MEDIS & 876,24 \\
\hline 4 & FASILITAS REHAB SOSIAL & 218,4 \\
\hline 5 & FASILITAS REHAB LINGKUNGAN & 364,8 \\
\hline 6 & FASILITAS RAWAT INAP PENYANDANG HIV & 999,6 \\
\hline 7 & SERVIS & 76,8 \\
\hline 8 & FASILITAS PENGELOLA & 81,6 \\
\hline 9 & FASILITAS PENUNJANG & 552 \\
\hline 10 & FASILITAS PARKIR & 529,2 \\
\hline & TOTAL LUAS BANGUNAN & $\mathbf{4 3 6 6 , 9 8}$ \\
\hline
\end{tabular}

\section{Analisis Pola Hubungan Ruang}

Pola hubungan ruang merupakan matrik penghubungan antara ruang sebagai tanda suatu hubungan ruang berdekatan atau tidak berdekatan. (lihat skema 1)

Skema 1. Pola hubungan ruang

MATRIX HUBUNGAN RUANG

\begin{tabular}{l}
\hline PENERIMAAN AWAL \\
\hline R. MANAJEMEN \\
\hline REHABILITASI MEDIS \\
\hline REHABILITASI SOSIAL \\
\hline REHABILITASI LINGKUNGAN \\
\hline R. RAWAT INAP \\
\hline SERVIS \\
\hline PENGELOLA \\
\hline PENUNJANG \\
\hline PARKIR \\
Keterangan: \\
+ Berdekatan \\
- Tidak Berdekatan \\
O Netral
\end{tabular}




\section{Analisis Pengelompokan Ruang}

Hasil matrik hubungan ruang didapatkan pengelompokan ruang yang merupakan gambaran dari denah kasar yang didapatkan berdasarkan analisis aktivitas, alur kegiatan, kebutuhan ruang. (lihat skema 2)

Skema 2. Pengelompokan hubungan ruang

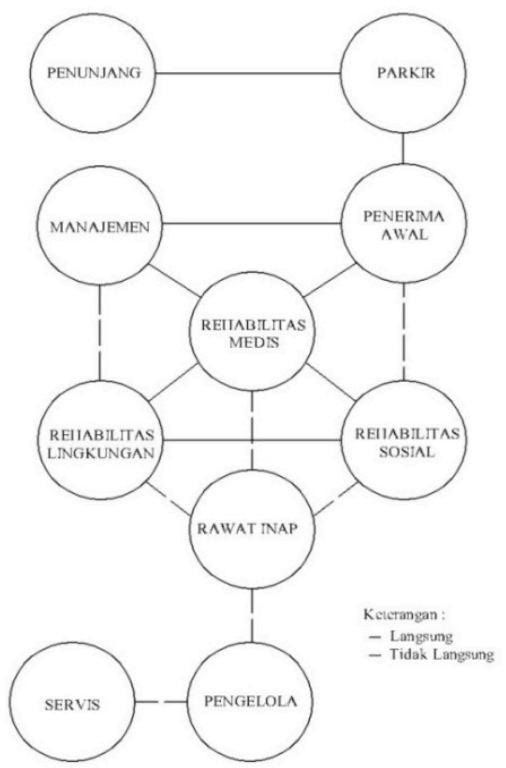

\section{Aspek Bangunan}

\section{Konsep Dasar Perancangan}

Konsep dasar perancangan "Pusat Rehabilitasi Penyandang HIV/AIDS di Pekanbaru" menggunakan topik arsitektur organik. Arsitektur organik adalah suatu konsep rancangan yang menginginkan hubungan keselarasan antara tapak dengan bangunannya.

Perancangan bentuk dan struktur bangunan didesain berdasarkan kebutuhan pemakai. Arsitektur organik dapat memberikan bentuk yang dinamis mengikuti perkembangan zaman tanpa menghilangkan unsur keasliannya.

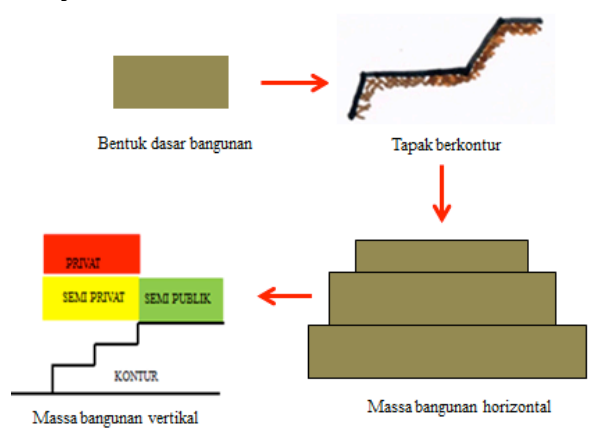

Gambar 7. Bentuk dasar bangunan

\section{Analisis Aspek Bangunan terhadap Arsitektur Organik}

Arsitektur organik merupakan penerapan hasil dari bentuk-bentuk biomorfik maupun hasil proses bentuk alam yang telah di produksinya. Bentuk bangunan dibuat menyesuaikan bentuk kontur.

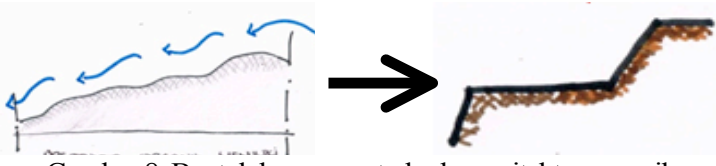

Gambar 8. Bentuk bangunan terhadap arsitektur organik

\section{Konsep Zoning}

Hasil dari pengambungan antara analisis manusia dan analisis tapak di dapatkan konsep zoning Pusat Rehabilitasi Penyandang HIV/AIDS di Pekanbaru. Terdapat pembagian menjadi lima zoning, yaitu:

a). Zoning publik merupakan area yang semua orang bisa memasukinya, terdiri atas area parkir dan taman. b). Zoning semi publik merupakan zona yang tidak semua orang boleh memasukinya terkecuali ada keperluan, terdiri atas ruang manajemen. c). Zoning semi privat merupakan area privat yang terbuka untuk umum dan tidak sembarang orang boleh masuk, terdiri dari ruang rehab medis, rehab sosial, rehab lingkungan, pengelola, servis. d). Zoning privat merupakan area privat, yang tidak boleh di masuki oleh orang umum, terdiri dari asrama rawat inap. e). Zoning servis merupakan servis suatu bangunan.

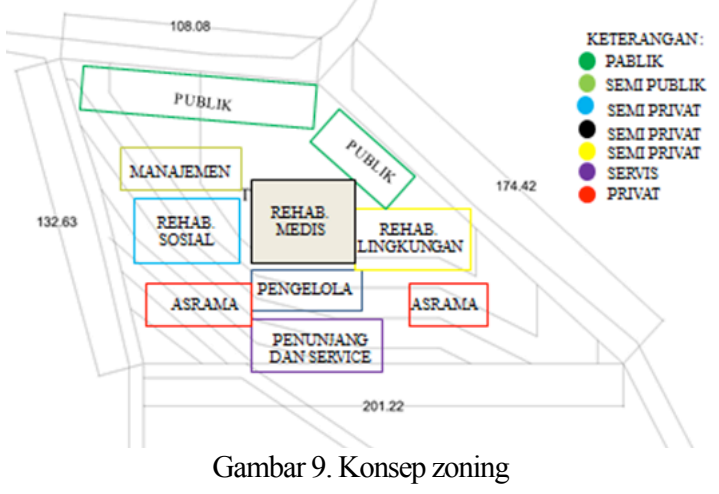

\section{Konsep Vegetasi}

Pada konsep tapak terdapat tiga jenis vegetasi yang memiliki fungsi yang berbeda, yaitu :a). Pohon tanjung merupakan tamanan peneduh, selain berfungsi sebagai peneduh kulit batang pohon tanjung dapat dijadikan obat demam, bunga nya dapat dijadikan sebagai pengharum ruangan. b). Pohon glodokkan tiang digunakan sebagai petunjuk arah. c). Tanaman hias berfungsi untuk menambah nilai estetika

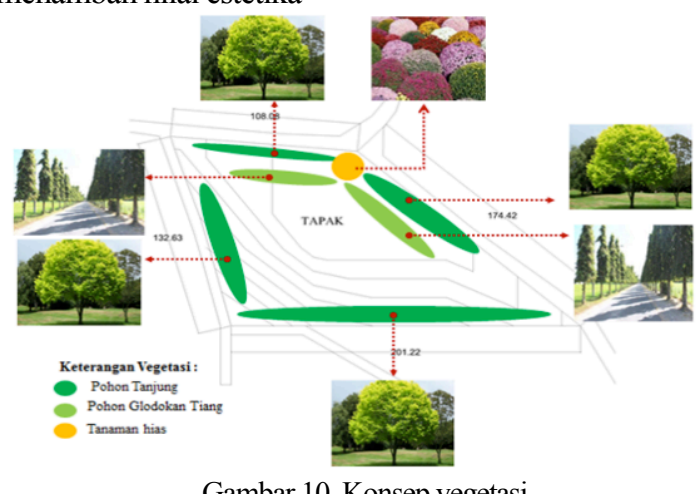

Gambar 10. Konsep vegetasi 


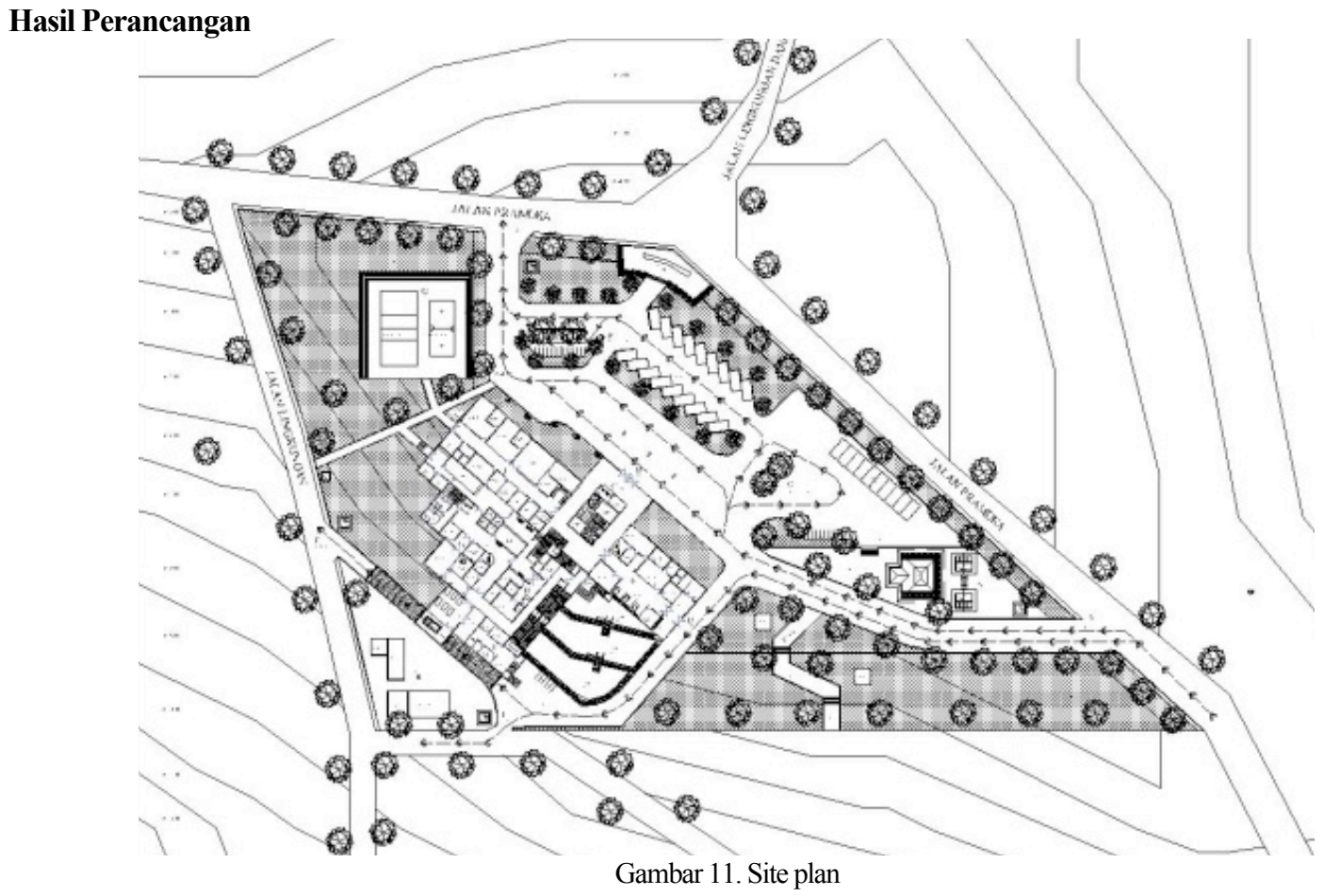

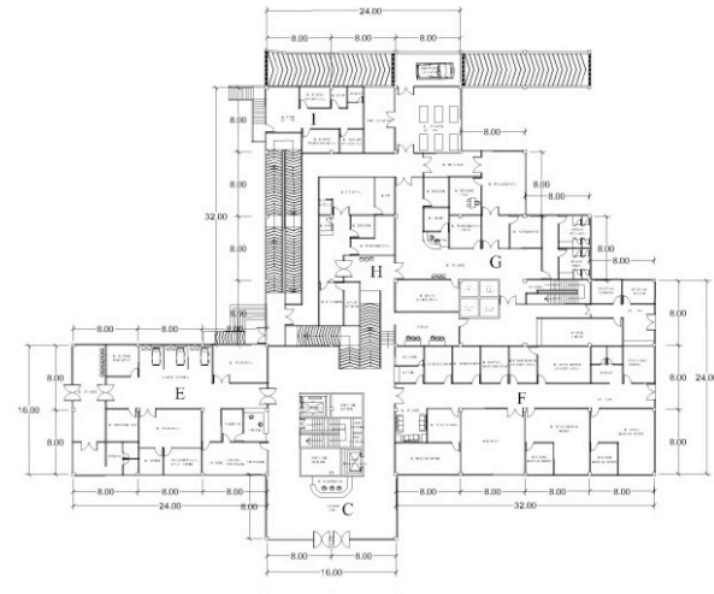

Gambar 12. Denah lantai 1

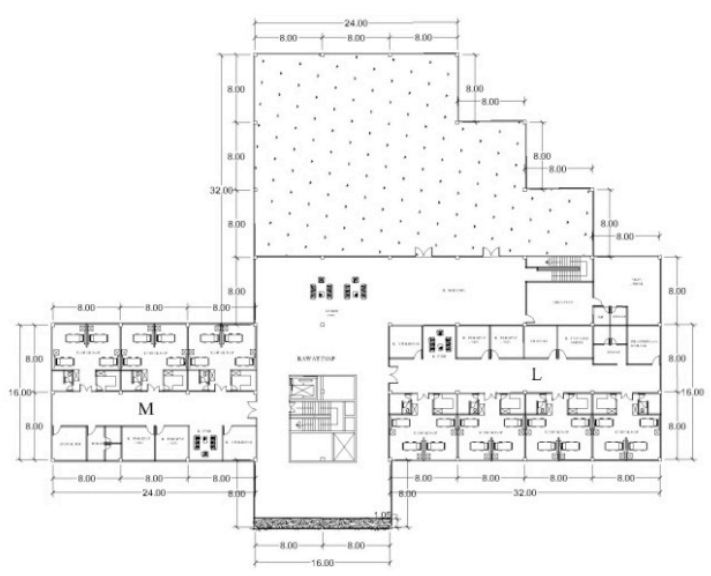

Gambar 14. Denah lantai 3

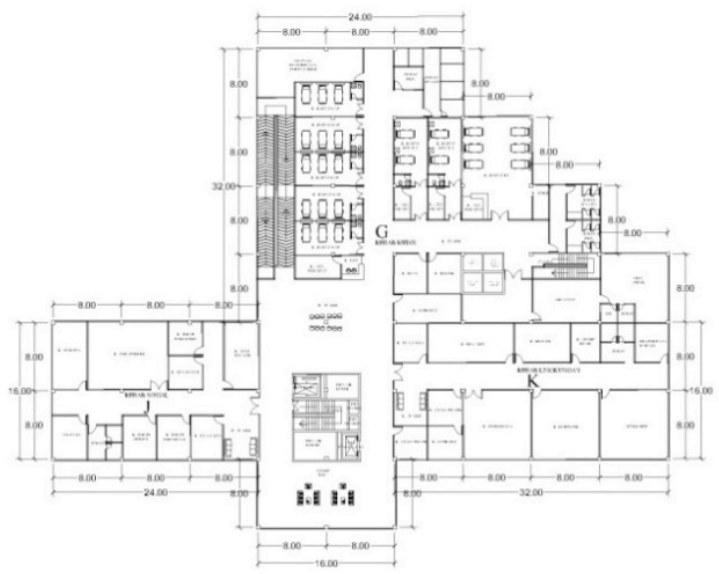

Gambar 13. Denah lantai 2

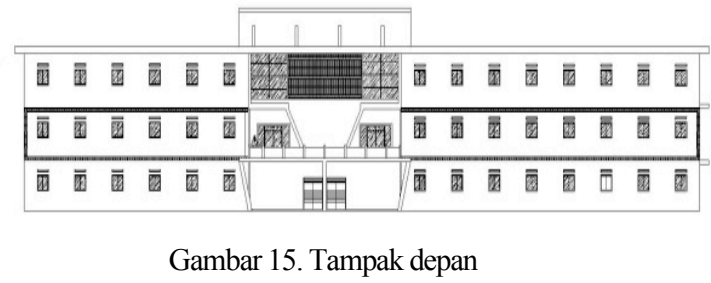




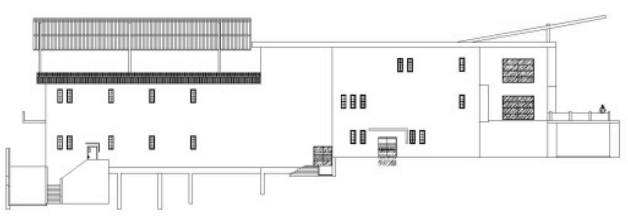

Gambar 16. Tampak samping kanan

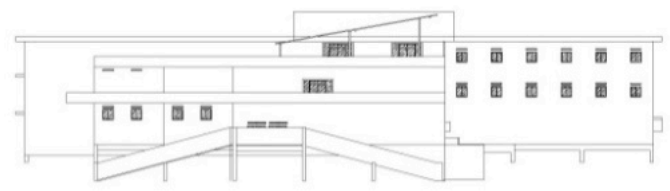

Gambar 18. Tampak belakang

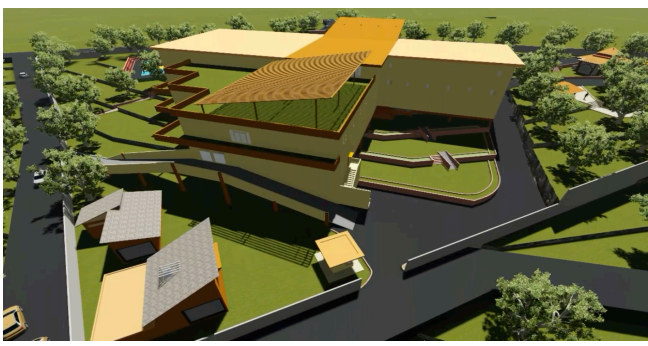

Gambar 20. Perspektif bangunan

\section{KESIMPULAN DAN SARAN}

Perencanaan "Pusat Rehabilitasi Penyandang HIV/AIDS di Pekanbaru" adalah sebagai pusat layanan pengobatan baik medis maupun non medis. Dengan tema pendekatan terhadap prinsip-prinsip Arsitektur Organik sehingga dapat menghasilkan bentuk bangunan yang selaras dengan lingkungan alam yang ada di sekitarnya.

Lokasi tapak berada di Jalan Pramuka, Rumbai Pesisir, Kota Pekanbaru, Riau. Dasar pemilihan tapak

\section{DAFTAR PUSTAKA}

1.Sumber Buku

Ching, Francis D.K, 2008. Arsitektur: Bentuk,Ruang Dan Tatanan Edisi Ketiga, Jakarta: PT. Erlangga Laksito, Buedhi. 2014. Metode Perencanaan dan Perancangan Arsitektur

Neufert, ernst. 1991. Data Arsitek edisi 33 jilid 2. Wiesbaden: Erlangga.

\section{Pustaka Internet}

http://riauterkini.com/lingkungan.php?arr=119910\&j udul $=2016, \% 20$ Kasus $\% 20$ HIV $/$ Aids $\% 20 \mathrm{di} \% 20$

Pekanbaru\%20Meningkat, Diakses tanggal 22 Februari 2018

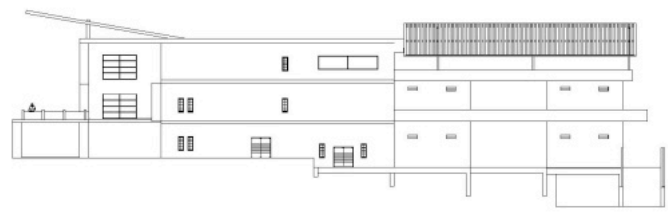

Gambar 17. Tampak samping kiri

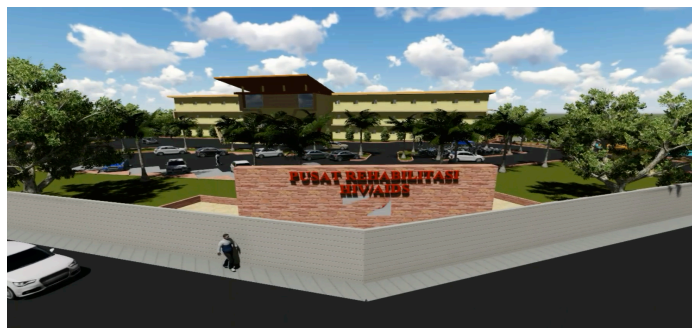

Gambar 19. Perspektif tapak dan bangunan

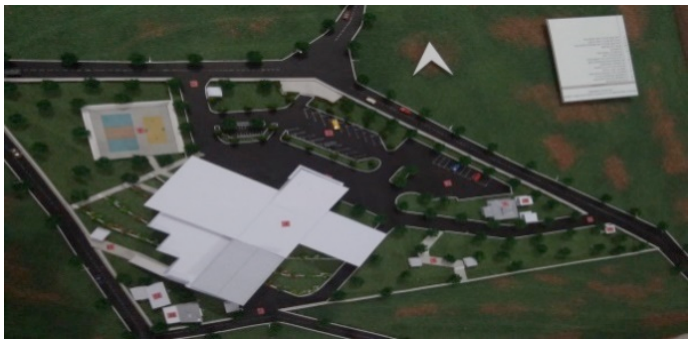

Gambar 21. Maket bangunan

didasarkan atas pemilihan kriteria-kriteria yang sesuai dengan topik dan tema. Lokasi tapak berada pada daerah strategis dengan view menghadap ke perkotaan.

Besar harapan dalam perencanaan "Pusat Rehabilitasi Penyandang HIV/AIDS di Pekanbaru" untuk dapat mewadahi seluruh penyandang HIV/AIDS yang ada di Riau, khususnya Kota Pekanbaru.

http://puspensos.kemsos.go.id/home/breng/494, Diakses tanggal 22 Februari 2018

http://www.spengetahuan.com/2016/01/12pengertian-rehabilitasi-menurut-para-ahliterlengkap.html, Diakses tanggal 7 Maret 2018 http://www.aidsindonesia.or.id/contents/37/78/InfoHIV-dan-AIDS\#sthash.Uc9Coptu.dpbs, Diakses tanggal 7 Maret 2018

http://hiv.autoimuncare.com/penyakit-hivdisebabkan-oleh/, Diakses tanggal 7 Maret 2018 http://himaartra.petra.ac.id/blog/2016/04/19/organicarchitecture/, Diakses tanggal 14 Mei 2018

http://architectureandbeauty.blogspot.co.id/2015/11/ aliran-arsitektur-organik.html, Diakses tanggal 